\title{
EKSISTENSI LABORATORIUM DAKWAH DI PTKI
}

\author{
Oleh: Nurhidayat Muhammad Said \\ Fakultas Dakwah dan Komunikasi \\ UIN Alauddin Makassar
}

\begin{abstract}
:
Dakwah Laboratory is an integral part in the implementation of teaching and learning process in the Faculty of Da'wah or Da'wah Department and is an institution that serves as the spearhead of the development of majors and courses in the Faculty of Da'wah. Dakwah Laboratory as a center of professional competence improvement of students in da'wah. Dakwah Laboratory as the center of gathering information of da'wah, both in relation to nature, character and problem faced by object of da'wah and potency which owned by ummah in supporting da'wah duty. To make themselves as the center of da'wah information, the Da'wah Laboratory should conduct da'wah research activities, so the information that is owned and developed in the training and practicum of dakwah is really based on accurate and realistic information.
\end{abstract}

\section{Keywords: \\ Existence, Laboratory, Da'wah}

\section{Pendahuluan}

Terjadinya ledakan informasi dan kemajuan teknologi dalam berbagai bidang tidak boleh dibiarkan lewat begitu saja. Umat Islam harus berusaha mencegah dan mengantisipasi dengan memperkuat aqidah yang berpadukan ilmu dan teknologi. Tidak sedikit umat yang telah menjadi korban dari efek globalisasi informasi yang membuat identitas keislamannya mengalami pengaburan dan masa depan generasi muda semakin suram. Jika umat Islam terlena oleh kemewahan hidup dengan berbagai pasilitasnya, maka secara perlahan akan meninggalkan ajaran agama. Dengan demikian akan terjadi kehampaan rohani yang justru merusak kepribadian setiap umat manusia. Di samping itu kelemahan dan ketertinggalan umat Islam dalam mengakses informasi dari waktu ke waktu, pada gilirannya juga akan membuat langkah-langkah dakwah kita semakin tertinggal. Dampak yang ditimbulkan dari ketertinggalan umat Islam dalam komunikasi global mengakibatkan posisi tawar peran dakwah Islam belum memiliki kekuatan yang signifikan. Kehadiran dunia Islam dalam komunikasi global, baru sebatas wacana yang memiliki potensi besar untuk bangkit. Media komunikasi yang banyak digunakan oleh Iran dalam membangun revolusinya belum memberikan andil yang kuat dalam percaturan global. Kantor-kantor berita di dunia Islam belum mampu berasaing dengan negara Barat dalam memasok berita utama di kalangan dunia Islam. ${ }^{1}$

Pada dasarnya kemajuan arus globalisasi informasi telah membawa pengaruh yang sangat besar terhadap tatanan kehidupan masyarakat. Tidak dapat dipungkiri bahwa 
peradaban modern yang sudah mengglobal telah memberikan kemudahan bagi umat manusia dalam menjalani aktivitas kehidupannya. Namun demikian dampak negatif yang ditimbulkan juga telah membawa berbagai permasalahan di dalam masyarakat. Begitu juga yang terjadi di Makassar, efek yang ditimbulkan kemajuan globalisasi ini telah memunculkan berbagai permasalahan umat.

Komunitas muslim adalah suatu komunitas yang ditegakkan atas sendi-sendi moral iman, Islam dan taqwa yang dipahami secara padu, utuh dan benar. Ini adalah suatu komunitas yang tidak eksklusif, karena ia berfungsi sebagai komunitas teladan di tengahtengah arus kehidupan yang penuh dinamika, tantangan dan pilihan-pilihan yang kadangkadang sangat dilematis. Hanya dengan kekuatan iman dan kecerdasan umat Islam akan dapat menetapkan pilihan yang tepat dalam menghadapi perubahan yang terjadi dalam masyarakat dan sekaligus memberi arah moral kepada perubahan itu. ${ }^{2}$

Sekarang ini Islam menghadapi sejumlah tantangan yang datang dari berbagai arah. Pemikiran meterialistik dan sifat individualistik telah banyak mempengaruhi pemikiran dan sikap hidup generasi muda Islam, sementara itu pula nilai-nilai moral yang islami mulai terkikis dalam tatanan masyarakat muslim. Pergeseran orientasi masyarakat terhadap nilainilai yang dianut sebagai akibat dari terjadinya perubahan pandangan, sikap, tingkah laku masyarakat yang bersangkutan. Hal ini tidak lepas dari proses interaksi antara over reality dan covert reality. Adapun faktor-faktor yang menyebabkan pergeseran tata nilai dalam suatu masyarakat antara lain: kemajuan ilmu pengetahuan dan teknologi, perkembangan dan kemajuan ekonomi, pengaruh kebudayaan luar dan sebagainya. ${ }^{3}$ Lemahnya penegakan hukum dan tatanan perundang-undangan yang digunakan, serta ketidakmampuan aparat memberikan jaminan keadilan, kemerdekaan dan kesetaraan telah memberikan kemungkinan bagi masuknya berbagai faham untuk menghancurkan umat dengan mengatasnamakan penegakan keadilan, pembelaan kepada kaum tertindas dan pemberantasan kemiskinan. ${ }^{4}$ Sebenarnya peperangan yang terjadi antara Islam dan kejahiliyahan tidak hanya pada level wacana saja, melainkan telah melangkah lebih jauh seperti dalam praktik politik dan monopoli ekonomi yang terkadang sangat merugikan dunia Islam.

Perkembangan ilmu pengetahuan dan teknologi telah membawa dampak yang sangat luar biasa dalam kehidupan masyarakat di seluruh dunia. Dampak positif dari kemajuan ilmu pengetahuan dan teknologi diantarnya adalah adanya kemudahan-kemudahan bagi manusia dalam menyelesaikan pekerjaan, meningkatnya wawasan dan pola pikir manusia dalam berbagai bidang kehidupan, dan meningkatnya kesejahteraan hidup manusia. Sementara dampak negatif yang ditimbulkan dari globalisasi adalah munculnya sikap materialisme, konsumerisme dan hedonisme dikalangan masyarakat dan berbagai macam penyakit sosial. ${ }^{5}$ Belum pernah ada peradaban yang begitu mendunia seperti mendunianya peradaban modern. Peradaban Islam memang juga pernah menyebar ke sebagian besar penjuru dunia, tapi ini masih sebatas pada daerah-daerah yang secara fisik berhasil dikuasai. Apa yang disaksikan saat ini adalah fenomena yang sama sekali lain. Peradaban modern 
menyebar tanpa ada kekuatan yang mampu menghalangi. Batas negara dan wilayah kekuasaan tidak lagi menjadi penghalang bagi masuknya unsur-unsur budaya modern (Barat). Setiap masyarakat yang kemudian termodernkan, menerima budaya modern secara suka rela sebagai bagian dari cara mereka untuk hidup secara terhormat dan maju.

Kota adalah wilayah yang paling banyak terkena arus modernisasi. Di kota lah kita temukan hampir seluruh simbol-simbol peradaban modern. Gaya hidup, mentalitas, budaya fisik adalah sebagian dari aspek kehidupan masyarakat kota yang telah sepenuhnya berkiblat pada peradaban modern.

\section{PEMBAHASAN}

\section{Dakwah dan Modernitas}

Di antara banyak ciri modernitas, terdapat dua ciri yang sangat menonjol yaitu individualisme dan materialisme. Sikap mental individualis dan materialis adalah dua ciri utama mentalitas peradaban modern. Di Makassar misalnya penerapan teknologi 'tepat guna' dalam pembangunan sulit menghindari meluasnya kesenjangan sosial. Hakikatnya penerapan ilmu pengetahuan dan teknologi tidak begitu ramah terhadap lapisan masyarakat kelas bawah. Munculnya kompleks-kompleks pemukiman yang mewah kian menjauhkan lapisan masyarakat bawah dengan masyarakat elit. ${ }^{6}$ Manusia modern adalah manusia yang dalam kehidupannya sangat mementingkan pencapaian-pencapaian pribadi daripada kolektif. Di tengah iklim kompetisi yang sangat tinggi, bahkan tidak jarang sangat keras, sikap individualis tampaknya seakan menjadi konsekuensi logis dari sebuah hubungan antar individu. Salah satu ilustrasi yang paling jelas dari sikap ini adalah sangat renggangnya hubungan ketetanggaan dan sikap acuh-tak acuh dengan apapun yang terjadi di sekitarnya sepanjang tidak menyangkut kepentingannya. Banyak contoh dapat kita sebut misalnya sikap diam orang-orang kota ketika melihat peristiwa penjambretan yang dilakukan di depan umum.

Demikian juga dengan sikap materialistik. Kapitalisme yang merupakan anak kembar modernisme mengajarkan sikap hidup dan sikap mental yang sangat materialistik. Rasionalitas, bagi manusia modern adalah rasionalitas kalkulatif-materialistik; rasionalitas yang dipenuhi oleh pertimbangan atau perhitungan untung rugi secara materialistik. Ekonomi kapitalistik masa sekarang adalah suatu kosmos raksasa tempat manusia dilahirkan dan menghadapkan dirinya kepada manusia, setidak-tidaknya sebagai individu, sebagai suatu tatanan segala hal yang tidak berubah yang didalamnya dia harus hidup. Hal ini memaksa setiap individu, sejauh dia terlibat dalam sistem hubungan pasar untuk menyesuaikan diri dengan aturan-aturan tindakan kapitalistik. Pengusaha pabrik yang pada jangka panjang bertindak berlawanan dengan norma-norma ini akan lenyap dari dunia ekonomi, seperti seorang pekerja yang tidak dapat atau tidak mau menyesuaikan diri dengan norma-norma kapitalisme pasti akan terlempar ke jalan tanpa memiliki pekerjaan. Kapitalisme sekarang yang telah mendominasi kehidupan perekonomian, mendidik dan memilih insan-insan ekonomi yang dibutuhkannya melalui proses "survival of the fittest" dalam bidang ekonomi. ${ }^{7}$ 
Segala sesuatu diukur berdasarkan materi. Dengan demikian, sesuatu dinilai berharga, jika secara material memberikan keuntungan. Orang-orang yang memiliki kelebihan atau kelimpahan materi akan mendapat tempat yang terhormat dalam sistem sosial modern.

Di tengah sikap mental materialistik, agama akan kehilangan daya tariknya karena agama tidak memberikan keuntungan material apapun bagi manusia. Itulah sebabnya beberapa ilmuwan sosial meramalkan bahwa semakin modern suatu masyarakat, semakin tersingkir pula agama dari kehidupan sosial masyarakat itu. Tidak ada agama yang bisa diharapkan akan bertahan lama jika berdasarkan kepercayaannya kepada asumsi-asumsi yang secara ilmiah jelas salah. ${ }^{8}$

Di kota-kota besar di Indonesia, sikap hidup materialistik menjadi gaya hidup yang seolah telah merasuk ke dalam relung hati terdalam masyarakat perkotaan. Agama mulai tersingkir dari pertimbangan-pertimbangan manusia kota dalam membuat keputusankeputusan penting dalam kehidupannya. Itu sebabnya, slogan bahwa masyarakat Indonesia adalah masyarakat yang relijius tampaknya menjadi klise dan kehilangan makna Mengapa umat Islam di Amerika mengalami perkembangan beberapa tahun terakhir ini karena secara ilmiah ajaran Islam mampu memberikan jalan keluar terhadap masalah yang dihadapi. Prof. Eric Lincoln, Dekan Fakultas Sosiologi Agama dalam sebuah pidato tentang dampak Islam di Amerika mengatakan: “ Dampak Islam terhadap orang hitam Amerika luar biasa. Sebelum mereka memeluk agama Islam, kaum non-muslim hitam hidup dalam kondisi yang terburuk. Setelah mereka memeluk Islam tingkat kehidupan sosial dan ekonominya jauh lebih tinggi. Di kalangan keluarga muslim hitam, tidak ada penyelewengan dan kecanduan di kalangan anak muda yang membuat masyarakat Amerika dalam keadaan panik. Bahkan orang-orang nonmuslim yang kecanduan obat terlarang, yang memeluk Islam mendapatkan latihan yang memungkinkan mereka melepaskan diri dari ketergantungan obat terlarang dan menjadi anggota masyarakat yang sangat produktif. Kaum muslim hitam Amerika sama sekali tidak mengganggu orang lain. Hanya ketika mereka diintimidasi atau diserang, mereka membela diri dengan segala kekuatan dan kemampuan yang ada pada mereka. ${ }^{9}$ Ini dibuktikan dengan semakin berkembangnya sikap hidup materialis dan permissive (serba membolehkan) di kotakota besar di Indonesia. Budaya yang sama sekali tidak mencerminkan relijiusitas semakin lama semakin transparan. Seks bebas menjadi gaya hidup baru yang tidak lagi dipermasalahkan. Jika diperhatikan bagaimana permissivenya budaya masyarakat kota maka bagaimana bisa masih saja menyebut masyarakat Indonesia sebagai masyarakat yang religius.

Jika diperhatikan problem-problem yang muncul dalam masyarakat modern (termasuk sikap mental individualis dan materialis), tampaknya hal itu tidak bisa lepas dari pandangan hidup humanistik yang merupakan cikal bakal peradaban Barat modern. Menarik untuk mencermati pernyataan Danah Zohar dan Ian Marshall dalam bukunya SQ: Memanfaatkan Kecerdasan Spiritual dalam Berpikir Integralistik dan Holistik untuk Memaknai Kehidupan, bahwa humanisme Barat pasca abad kedelapan belas secara spiritual bodoh ${ }^{10}$. 
Mengenai humanisme, peradaban Barat adalah contoh yang buruk. Humanisme Barat lahir dari pemberontakan terhadap kekuasaan Gereja yang bersifat dogmatis pada abad Pertengahan. Gereja tidak hanya menentukan apa yang boleh dan tidak boleh dikerjakan oleh manusia tapi juga apa yang boleh dan tidak boleh dipikirkan. Renaissance berusaha merebut kembali kedaulatan manusia yang selama berabad-abad direnggut dari dirinya. Mungkin akan terlihat bahwa perkembangan semangat kapitalisme paling baik dipahami sebagai bagian dari perkembangan rasionalisasi secara keseluruhan dan dapat disimpulkan dari posisi fundamental dari rasionalisme pada masalah yang paling mendasar dari kehidupan. Akan tetapi rasionalisasi tadi masih berada pada tahap yang terbelakang di beberapa negara dengan tingkat rasionalisasi ekonomi paling tinggi di Inggris, negara dimana Renaisance dari hukum Roma diatasi dengan kekuasaan korporasi hukum yang hebat. ${ }^{11}$ Inilah yang disebut antroposentrisme yang tak lain adalah humanisme versi peradaban modern Barat.

Melalui antroposentrisme atau humanisme antroposentris, peradaban Barat mengalami revolusi. Pandangan antroposentris beranggapan bahwa kehidupan tidak berpusat pada Tuhan tapi pada manusia. Etosnya adalah semangat menghargai nilai-nilai yang dibangun oleh manusia sendiri. Kemenangan pun kini ada di pihak manusia. Tuhan "tidak berdaya" menghadapi pemberontakan manusia. Maka dimulailah geliat baru sebuah peradaban besar, peradaban yang menjadikan manusia sebagai tolok ukur kebenaran dan kepalsuan, untuk memakai manusia sebagai kriteria keindahan dan untuk memberikan nilai penting pada bagian kehidupan yang menjanjikan kekuasaan dan kesenangan manusia. Antroposentrisme menganggap manusia sebagai pusat dunia, karenanya merasa cukup dengan dirinya sendiri. Dalam zaman Renaisance manusia mulai dianggap sebagai pusat realitas. Perubahan radikal ini berbeda dengan corak pemikiran dua zaman sebelumnya, yaitu zaman Yunani Kuno dan Abad Pertengahan. Pada Zaman Yunani dan Abad Pertengahan, para pemikir menemukan masing-masing unsur kosmologis dan Tuhan sebagai substansi atau prinsip induk. Sedangkan para pemikir zaman Renaisance yang mengalami pencerahan (aufklarung) menemukan manusia sendiri sebagai "prinsip induk." Manusia sendiri mengambil peranan sebagai subyek. Kebenaran tidak lagi menjadi monopoli agama dalam hal ini gereja. ${ }^{12}$

Selama dua atau tiga ratus tahun lebih manusia modern membatasi pandangannya hanya pada manusia. Akibatnya mereka jatuh ke dalam egoisme diri yang memutuskan hubungan dari makna dan perspektif yang lebih luas. Manusia modern banyak mencari kesenangan dan kepuasan yang dekat (di sini dan saat ini, duniawi) daripada kesenangan dan kebahagiaan dari perspektif yang lebih jauh dan mendalam (misalnya kebahagiaan di akhirat). Ini disebabkan karena manusia telah kehilangan kemampuan untuk membayangkan hal yang lebih jauh dari dirinya sendiri. Para pemikir besar Zaman Pencerahan abad kedelapan belas menyatakan bahwa manusia merupakan ukuran segala sesuatu. ${ }^{13}$

Antroposentrisme ini kemudian pada gilirannya menghilangkan fungsi transendensi pada diri manusia. Setiap manusia yang dilahirkan di dunia ini dalam lingkungan individual 
atau sosial apa pun, menginginkan kesempurnaannya sendiri sesuai dengan watak dan akal bawaannya. Ia menanggung segala macam penderitaan dan kesukaran demi harapannya akan masa depan yang lebih baik. Titik tolaknya adalah kekurangan dan gerakannya menuju kesempurnaan. Akal dan ruhani manusia memberikan suatu kedalaman, kekuatan dan kecepatan yang sedemikian rupa kepada gerakannya menuju kesempurnaan. Dr. Alexis Carrel, ilmuwan Prancis mengatakan kita harus membiasakan diri untuk membedakan cahaya dan kegelapan, kemudian menetapkan diri kita untuk mengelakkan keburukan dan merangkul kebaikan. Namun, pemantangan dari keburukan memerlukan kesehatan tubuh dan jiwa. Pertumbuhan yang bertujuan dari tubuh dan jiwa tidaklah mungkin tanpa bantuan penyucian diri. ${ }^{14}$ Manusia karena merasa menjadi pusat dunia, cenderung menfokuskan segala sesuatu pada diri sendiri. Akibatnya dia tidak mampu keluar dari batasan diri sendiri. Cara pandang dan sikap mental manusia modern bersifat sangat terbatas dan tidak mampu menjangkau dimensi yang lebih luas, lebih jauh dan lebih tinggi dari pada dirinya sendiri.

Itulah sebabnya kenapa Zohar menyebut humanisme Barat sebagai humanisme yang miskin spiritual atau humanisme yang secara spiritual bodoh. Dengan bahasa lain, kecerdasan spiritual (SQ) manusia yang berangkat dari cara pandang antroposentris rendah. SQ memungkinkan manusia untuk keluar dari batasan karena itu mampu bermain dengan batasan, bukan sekedar bermain di dalam batasan. Kecerdasan spiritual memberikan kepada manusia kemungkinan untuk "memainkan permainan tak terbatas"15. Bagi mereka yang memiliki kecerdasan spritual maka segala hal yang dianggap sebagai berbahaya tidak menjadi masalah baginya, karena memiliki kematangan spritual.

Tidak dapat dipungkiri bahwa di kota kita menyaksikan munculnya tindakan kekejaman yang berkecamuk seperti kerusuhan, perkelahian, tawuran, penjarahan, perampokan dan pembunuhan. Ada yang beranggapan bahwa semua itu terjadi karena ketidakpercayaan kepada aparat penegak hukum dan aparat keamanan yang tidak mampu lagi menjamin keadilan dan tegaknya hukum. Juga ada pandangan bahwa masyarakat banyak mengalami frustasi berat, karena tekanan ekonomi yang telah banyak menimbulkan pengangguran dan berdampak pada kemiskinan. Terciptanya kemiskinan, menurut Amartya Sen (Peraih nobel di bidang ekonomi 1998), karena pendapatan (lack of income) bukan karena kurangnya kemampuan (lack of capability). Dengan kata lain, seorang menjadi miskin bukan karena kurangnya kemampuan yang ada pada dirinya melainkan karena kurangnya kesempatan untuk mendapatkan pendapatan tersebut sehingga ia menjadi miskin. Asumsinya jika setiap warga negara diberi kesempatan yang sama dalam berbagai kesempatan untuk meraih pendapatan, maka kemiskinan secara tidak langsung dapat diatasi. ${ }^{16}$

Terlepas dari semua pandangan di atas, tetapi yang pasti semua itu disebabkan karena adanya krisis moralitas yang telah melanda masyrakat. Kehidupan kini dipenuhi dengan nilainilai materialistik, membuat bingung masyarakat dan kehilangan pegangan hidup. Mereka membutuhkan ajaran yang dapat mengembalikan kesucian diri sebagai manusia. 
Dengan demikian peranan dakwah sangat dibutuhkan dalam upaya memperbaiki dan mengarahkan umat pada jalan kebenaran. Sementara itu, dakwah untuk mengembalikan ummat manusia kepada fitrahnya, nampak kehilangan ruh (hakekat dan semangat dakwah). Sehingga, dakwah tidak memiliki metode, pedoman dan arahan yang jelas. Terutama untuk menjadikan kaum muslimin sebagai khairu ummah, yang dapat memainkan peran utama dalam kancah kepemimpinan dunia, dan teladan di tengah masyarakat.

Bertolak dari faktor-faktor tersebut, agar problematika dakwah tidak semakin kusut dan berlarut-larut, perlu segera dicarikan jalan keluar dari kemelut persoalan yang dihadapi itu. Dalam konsep pemikiran yang praktis M. Amien Rais, dalam bukunya Moralitas Politik Muhammadiyah, menawarkan lima "Pekerjaan Rumah" yang perlu diselesaikan, agar dakwah Islam di era informasi sekarang tetap relevan, efektif, dan produktif.

Pertama, perlu ada pengkaderan yang serius untuk memproduksi juru-juru dakwah dengan pembagian kerja yang rapi. Ilmu dakwah belaka tidak cukup untuk mendukung proses dakwah, melainkan diperlukan pula berbagai penguasaan dalam teknologi informasi yang mutakhir.

Kedua, setiap organisasi Islam yang berminat dalam tugas-tugas dakwah perlu membangun laboratorium dakwah. Dari hasil "Labda" ini akan dapat diketahui masalahmasalah riil di lapangan, agar jelas apa yang akan dilakukan.

Ketiga, proses dakwah tidak lagi terbatas pada dakwah bi al-lisan, tapi harus diperluas dengan dakwah bi al-hâl, bi al-khitâbah (lewat tulisan), bi al-hikmah (dalam arti politik), bi al-iqtishâdiyah (ekonomi), dan sebagainya. Yang jelas, actions, speak louder than word.

Keempat, media massa cetak dan terutama media elektronik harus dipikirkan sekarang sebagai media dakwah. Media elektronik yang dapat menjadi wahana atau sarana dakwah perlu dimiliki oleh umat Islam. Bila udara Indonesia di masa depan dipenuhi oleh pesan-pesan agama lain dan sepi dari pesan-pesan Islami, maka sudah tentu keadaan seperti ini tidak menguntungkan bagi peningkatan dakwah Islam di tanah air.

Kelima, merebut remaja Indonesia adalah tugas dakwah Islam jangka panjang. Anakanak dan para remaja adalah aset yang tidak ternilai. Mereka wajib selamatkan dari pengikisan aqidah yang terjadi akibat 'invasi' nilai-nilai non islami ke dalam jantung berbagai komunitas Islam di Indonesia. Bila anak-anak dan remaja kita memiliki benteng tangguh (alhusus al-hamidiyyah) dalam era globalisasi dan informasi sekarang ini, maka dapat disimpulkan bahwa masa depan dakwah akan tetap ceria. ${ }^{17}$

Tawaran Amin Rais ini sangat berasalan mengingat kondisi masyarakat sekarang ini sedang berada dalam era globalisasi informasi. Maka tidak dapat dihindari, aktivitas dakwah harus turut serta dalam percaturan global. Internet yang dianggap sebagai media komunikasi mutakhir saat ini harus diisi dengan agenda dakwah global. Isu-isu negatif terhadap dunia internet harus diimbangi dengan isi pesan-pesan dakwah yang mencerahkan dan menggugah hati dan pikiran bagi yang mengaksesnya. 
Konsep Laboratorium Dakwah ini sebenarnya sudah lama digulirkan oleh Amrullah Ahmad agar perguruan tinggi Islam yang memiliki fakultas dakwah mendirikan Labda. Keberadaan Labda sangat menentukan keberhasilan suatu dakwah. Dengan munculnya lembaga-lembaga Islam maka tentunya sangat diharapkan sumbangsih besar dari alumni fakultas dakwah jurusan manajemen dakwah. Kemajuan ilmu pengetahuan dan teknologi modern menuntut lembaga-lembaga Islam harus melakukan pengelolaan dengan sistem manajemen modern. Begitu pula dengan kegiatan dakwah yang selama ini masih sering diakukan pengelolaan secara individu, maka untuk saat ini dan masa mendatang harus dilakukan secara kelompok sehingga memerlukan manajemen profesional. Jika masih menggunakan sistem lama maka suatu saat aktivitas dakwah ini tidak mampu bersaing dengan kegiatan lainnya yang dikelola secara sistematis.

Model dakwah verbal yang penuh retorika itu hanya melahirkan umat yang kesiapan utamanya hanyalah mendengarkan segala petuah yang disampaikan muballig. Orang-orang datang ke tempat pengajian sama dengan anak sekolah yang datang ke lapangan mengikuti upacara, datang, dengar dan pulang. Atau seperti golongan sakit hati yang mengharapkan muballig melontarkan kritikan dan makian sebagai hiburan yang memuaskan mereka lantas dibawa pulang dan tidur pulas. Akibat dari semua itu adalah lahirnya umat yang hanya manut, tergantung, pasif dan menuntut. Faktanya sekarang umat lebih banyak menuntut keteladanan, aplikasi dari apa yang telah disampaikan oleh muballig. Salah satu peroblema dakwah saat ini adalah umat mengalami krisis keteladanan dari mereka-mereka yang dianggap muballig. Meskipun dakwah bi al-lisan itu penting, karena manusi itu tergugah motivasinya melalui penggerakan ide yang dicetuskan dengan kata-kata, namun dakwah bi al-lisan hanya efektif jika diikuti dengan dakwah bi al-hal. ${ }^{18}$

Dari uarain di atas, dapat diprediksi bahwa missi dan tantangan dakwah akan semakin berat dan hebat bahkan semakin kompleks dan melelahkan. Inilah problematika dakwah kita masa kini. Oleh sebab itu semuanya harus dikelola dengan manajemen dakwah yang profesional oleh tenaga-tenaga dakwah yang berdedikasi tinggi, mau berkorban dan ikhlas beramal. Aktivitas dakwah tidak lagi menganut paham sambil lalu mengingat semakin kompleksnya persoalan yang dihadapi oleh umat dewasa ini. Oleh karena itu aktivitas dakwah tidak dapat dipandang sebagai kegiatan individual semata dalam sisi operasionalnya, tetapi harus dipandang sebagai aktivitas kelompok yang membutuhkan manajemen yang profesional jika ingin setiap aktivitas dakwah itu punya target konkrit. Aktivitas dakwah yang tidak direncanakan secara baik akan berakibat pada kegagalan jika strategi yang dilaksanakan tidak tepat. Bahkan boleh jadi akan membuat audiens tidak mendengarnya atau bahkan menolaknya.

Dakwah perlu diformat ulang, artinya umat Islam perlu merancang ulang pemahaman atas dakwah yang dijalankan, mesti mengetahui makna dan tujuan dakwah yang mereka lakukan. Mestinya dakwah merupakan kegiatan yang mendorong pencapaian kemajuan dunia namun berlandaskan agama. Jadi dakwah itu bukan hanya mengaji, ceramah atau tabligh. 
Selama ini dakwah sering dipahami secara sempit oleh sebagian masyarakat. Pemahaman yang sempit itu jelas keliru serta mempersempit arti dan pengertian dakwah itu sendiri, sebab mengaji, ceramah atau tabligh hanyalah bahagian kecil dari aktivitas dakwah. Untuk memahami dakwah diperlukan dua pendekatan yaitu: pertama, memahami dakwah sebagai ilmu pengetahuan. Kedua, memahami dakwah secara praktis sebagai suatu tindakan dan aksi untuk dikembangkan. ${ }^{19}$

Dengan pemahaman itu dakwah bisa dilakukan dengan membangun lembaga pelatihan yang bertujuan untuk menyiapkan generasi muslim yang sejahtera secara duniawi yang sekaligus memiliki moralitas agama. Ini lebih baik hasilnya dibandingkan dakwah selama ini yang lebih banyak menekankan pada kehidupan akhirat.

Program dakwah yang mungkin bisa dilakukan, adalah dengan menyiapkan generasi muda Islam untuk mendapatkan keterampilan hidup. Pembinaan kaderisasi da'i dimaksudkan agar mereka memiliki kecakapan dan keterampilan berdakwah, baik dalam bentuk dakwah $b i$ al-lisan al-maqal maupun dalam bentuk bi al-lisan al-hal. Karen itu kepada mereka perlu dilengkapi bekal pengetahuan dan keterampilan melalui penataran-penataran dan balai latihan kerja. ${ }^{20}$ Ini dilakukan agar mereka mampu bersaing secara duniawi dan mereka pun memiliki dasar moral agama yang kuat. Penulis beranggapan langkah ini akan lebih memberikan dampak yang kuat dibandingkan cara konvensional.

\section{Eksistensi Laboratorium Dakwah di PTKI}

Eksistensi Fakultas Dakwah atau jurusan Dakwah dalam lingkup PTKI adalah menyelenggarakan pendidikan tinggi dan penelitian serta pengabdian kepada masyarakat di bidang dakwah. Untuk merealisir tujuan tersebut maka dibukalah jurusan yang masingmasing memiliki tujuan untuk mendidik cendekiawan muslim berstrata satu (S.1) yang memiliki aqidah Islam yang kuat, berfikrah islami, istiqomah dalam bersikap dan bertindak menurut Islam dan memiliki ketrampilan (skill) sesuai jurusan masing-masing.

Untuk mewujudkan tri darma tersebut maka dibutuhkan muatan kurikulum, Sumber Daya Manusia (SDM) yang tersedia dan memadai terutama berkaitan dengan tenaga pengajar (dosen), pelaksanaan Proses Belajar Mengajar (PBM) dan evaluasi, serta yang tidak kalah pentingnya adalah tersedianya laboratorium yang merupakan perangkat penunjang pelaksanaan pendidikan. Laboratorium merupakan tempat pembekalan, pembinaan bagi sivitas akademika agar lebih berkualitas di dalam mengusai ilmu pengetahuan akademik dan pendidikan keterampilan profesional.

Laboratorium Dakwah merupakan bagian integral dalam pelaksanaan proses belajar mengajar di Fakultas Dakwah atau jurusan dakwah dan merupakan institusi yang berfungsi sebagai ujung tombak pengembangan jurusan dan program studi di Fakultas Dakwah. Untuk saat ini setidaknya fasilitas laboratorium dakwah dilengkapi ruangan-ruangan khusus dan juga kelengkapan peralatannya, seperti: (1) Laboratorium Broadcasting, yang dilengkapi dengan Ruang Studio Siaran Radio dan Ruang Studio Produksi Siaran Radio kedap suara lengkap 
dengan peralatan siarnya. Selain itu juga dilengkapi dengan Ruang Production House (Produksi Siaran TV dan Film) kedap suara lengkap dengan peralatannya . (2) Laboratorium Publishing, yang dilengkapi dengan ruang percetakan lengkap dengan peralatan cetak. (3) Laboratorium Media Tradisional, yang dilengkapi dengan ruang micro preaching, yang dilengkapi dengan peralatan modern, seperti video shooting. Selain itu lab ini memiliki peralatan tradisional, seperti rebana, kecapi, gambus dan sebagainya. (4) Laboratorium Konseling, yang dilengkapi dengan ruang kedap suara untuk latihan dan praktek konseling. Selain itu, untuk melaksanakan fungsi lab ini telah dibentuk Lembaga Bimbingan Konseling Islami (LBKI). (5)Laboratorium Penelitian dan Pengembangan Dakwah, yang dilengkapi dengan operation room lengkap dengan berbagai peralatan, seperti computer, yang berfungsi sebagai penyusunan data dan pusat informasi data. Selain itu tersedia ruangan seminar dan diskusi dengan kapasitas 200 orang. (6) Divisi Kelembagaan Islam, yang dilengkapi dengan ruang ekspose lengkap dengan peralatan-peralatan presentasi, seperti Laptop, LCD, OHP, dan lain-lain. Selain itu juga terdapat ruang praktikum manajemen kelembagaan Islam, seperti menejemen wisata religious, haji dan umroh. Namun yang menjadi permasalahan adalah bahwa keberadaan Laboratorium Dakwah dengan segala perlengkapan dan peralatannya sebagaimana yang telah tersebut belum benar-benar menjadi institusi yang diidealkan oleh mahasiswa. Mahasiswa belum banyak yang merasakan peran dan fungsi laboratorium dakwah dalam peningkatan kualitas akademik mereka. ${ }^{21}$

\section{Fungsi Laboratorium Dakwah}

Pada hakekatnya laboratorium dakwah memiliki fungsi sebagai berikut:

1. Laboratorium merupakan perangkat penunjang pelaksanaan pendidikan dalam bidang akademik dan atau professional.

2. Universitas, Institut, sekolah Tinggi dan fakultas bertanggung jawab dalam penyelenggaraan laboratorium.

3. Laboratorium merupakan tempat pembekalan, pembinaan bagi sivitas akademika agar lebih berkualitas di dalam menguasai ilmu pengetahuan dan keterampilan professional.

4. Laboratorium berfungsi untuk menunjang peningkatan kualitas pendidikan, pengembangan ilmu dan penerapannya dalam kehidupan masyarakat.

5. Tujuan penyelenggaraan laboratorium adalah untuk menunjang, memperlancar serta meningkatkan kualitas pelaksanaan pendidikan baik dalam bidang pendidikan akademik dan atau professional

Menurut Amrullah Ahmad, Laboratorium Dakwah adalah lembaga yang melakukan penelitian, pengembangan dan uji coba teori, model dan program dakwah Islam, baik yang berkaitan dengan dakwah billisan (Komunikasi dan Penyiaran Islam, serta Bimbingan dan Penyuluhan Islam), dakwah bilhal (Pengembangan Masyarakat Islam), maupun dakwah bittadbir (Menejemen Dakwah) yang dilaksanakan di suatu tempat tertentu, dengan tujuan supaya kegiatan teoritik dakwah memiliki relevansi dengan realitas dakwah, dan kegiatan 
empiris dakwah memiliki akar teoritik yang jelas sehingga sasaran dan tujuan dakwah dapat tercapai.

Menurut Amrullah Ahmad, dalam wujudnya laboratorium dakwah dapat terdiri dari 2 (dua) bagian, yaitu laboratorium klasikal dan laboratorium bina masyarakat (Desa bina). Pertama, Laboratorium Klasikal adalah laboratorium yang menempati ruangan tertentu dalam kampus yang didalamnya terdapat berbagai macam peralatan-peralatan dan kegiatan, seperti penyusunan desain model, analisa dan uji coba dakwah Islam pra-lapangan dilaksanakan. Demikian juga hasil implementasi uji coba lapangan dianalisa dan dievaluasi menurut criteria dan standart program yang sudah ditetapkan. ${ }^{22}$ Hasil analisa dijadikan dasar untuk mendesain ulang model dakwah atau untuk menyempurnakan desain model yang sudah ada. Struktur laboratorium klasikal ini paling tidak meliputi:

a. Data Base, tentang profil lokasi atau sasaran dakwah, profil da'i, kepemilikan sarana komunikasi.

b. Peta Dakwah

c. Rancangan model dakwah

d. Aplikasi model dalam praktek

e. Pengolahan masukan aplikasi model dari lapangan

f. Analisa refleksi model dan abstraksi implementasi model.

Kedua, Laboratorium Masyarakat, yaitu laboratorium yang berada diluar kampus, dan berada pada suatu wilayah tertentu. Yang wujudnya dapat berupa: desa binaan, lembaga dakwah, lembaga profesional, dan lain-lain. Sebagai institusi pengembangan jurusan dan program studi maka Laboratorium Dakwah berperan sebagai :

1) Laboratorium Dakwah sebagai pusat peningkatan kompetensi profesionalitas mahasiswa dalam berdakwah. Sehingga Laboratorium Dakwah diharapkan dapat berguna sebagai wahana untuk melatih mahasiswa agar benar-benar memiliki keterampilan dan keahlian dalam berdakwah yang sesuai dengan jurusan dan program studi yang ditekuni.

2) Laboratorium Dakwah sebagai pusat penghimpun informasi-informasi dakwah, baik dalam hubungannya dengan sifat, karakter dan problem yang dihadapi oleh obyek dakwah maupun potensi-potensi yang dimiliki oleh umat dalam mendukung tugas dakwah. Untuk menjadikan diri sebagai pusat informasi dakwah maka Laboratorium Dakwah harus melakukan kegiatan penelitian dakwah, sehingga informasi yang dimiliki dan dikembangkan dalam pelatihan dan praktikum dakwah benar-benar disandarkan pada informasi yang akurat dan realistik.

3) Laboratorium Dakwah sebagai pusat pelayanan dan pengabdian masyarakat. Artinya, Laboratorium Dakwah dapat memberikan informasi-informasi dan bimbingan kepada pemakai jasa dakwah, baik secara langsung maupun melalui media tertentu dalam bentuk konsultasi, penyuluhan, dan kegiatan-kegiatan lainnya. 
Sedangkan menurut Amrullah Ahmad, bahwa Laboratorium Dakwah memiliki fungsi mikro dan fungsi makro, yaitu :

a) Fungsi Mikro Laboratorium Dakwah, yaitu fungsi dalam kaitannya dengan pendidikan atau Fakultas Dakwah. Fungsi ini meliputi :

1) Tempat merancang model-model dakwah Islam yang relevan dengan kondisi dan kebutuhan masyarakat.

2) Tempat praktikum mahasiswa untuk mata kuliah yang perlu pendalaman teknis dan ujicoba model dakwah dalam praktek.

3) Tempat rekayasa masa depan umat dalam mencapai tujuan dakwah Islam.

4) Pusat informasi menejemen pengembangan sistem pemdidikan ilmu dakwah

5) Tempat beramal sholeh, karena kegiatan aplikasi model dakwah dalam masyarakat adalag wujud nyata amal sholeh mahasiswa dan dosen dalam memecahkan dan mengantisipasi masalah umat Islam dalam didang social, ekonomi, dan lingkungan dalam perspektif Islam.

6) Tempat membangun teori "dakwah baru" setelah "teori lama" runtuh ditelan realitas masyarakat. Gejala dakwah dalam masyarakat tidak dapat lagi dijelaskan dan dikontrol dengan teori yang dimaksud.

b) Fungsi Makro Laboratorium Dakwah, yaitu fungsi terkait dengan kegiatan dakwah umat Islam. Fungsi ini meliputi :

1) Pusat informasi dakwah bagi lembaga-lembaga dakwah Islam.

2) Pengaya teori dan model dakwah bagi pelaksanaan dakwah Islam.

3) Sebagai jembatan keilmuan, karena pendidikan tinggi belajar bersama dan dari masyarakat. Sebaliknya masyarakat belajar bersama dan dari perguruan tinggi.

Masyarakat ditempatkan sebagai sumber ilmu yang kontektual, sedangkan perguruan tinggi ditempatkan sebagai juru bahasa masyarakat menurut kondisi nyata yang melingkupi kehidupan mereka.Mengingat fungsinya yang demikian luas, maka Laboratorium Dakwah harus memiliki berbagai divisi (kompartemen) untuk menjalankan secara spesifik fungsifungsi di atas, kompartemen tersebut dapat dibuat berdasarkan paradigma akademikkeilmuan, paradigma profesional, dan paradigma sosial; serta paling tidak dapat mencakup berbagai area masalah seperti :

1. Peta Dakwah

Problem mendasar yang dihadapi oleh dakwah sekarang ini adalah kesenjangan konstruk dakwah dengan realitas sosial. Dakwah seringkali dijalankan tanpa melihat dan menjawab realita permasalahan yang dihadapi masyarakat. Hal demikian telah membawa dakwah menjadi idealistik, bukan utopis. Untuk mengurangi kesenjangan tersebut pembuatan peta dakwah baik dalam skala nasional maupun lokal merupakan keniscayaan; karena dengan peta dakwah seluruh permasalahan akan tergambar dengan jelas dan obyektif, yang kemudian dakwah akan lebih terfokus dan kontekstual. Pembuatan peta dakwah merupakan 
kompartemen pertama dalam Laboratorium Dakwah dengan didukung seperangkat komputer dan tenaga yang profesional.

2. Ruangan Rekayasa Dakwah

Membuat solusi yang tepat, sistematis dan operasional terhadap permasalahan dakwah merupakan problem lain yang perlu mendapatkan perhatian. Meskipun data lapangan sudah terdokumentasi dengan baik, ternyata masih dibutuhkan kompartemen tersendiri yang akan menganalisis prioritas masalah dan solusi yang akan diambil. Melalui proses yang demikian akan diperoleh kejelasan arah persyaratan-persyaratan yang harus diambil dan tahapantahapan sistematis yang harus ditempuh.

3. Menejemen Dakwah

Kemampuan dan kecakapan menejerial merupakan problem lain yang cukup serius. Perencanaan, organisasi, pelaksanaan dan evaluasi seringkali tidak dilaksanakan. Kalaupun dilaksanakan, seringkali tidak ada konsistensi. Oleh sebab itu peningkatan kualitas Sumber Daya Manusia (SDM) di bidang menejemen harus merupakan prioritas lain dari laboratorium dakwah dan akan ditangani oleh kompartemen khusus.

4. Media Elektronik (Televisi dan Radio)

Problem lain yang cukup menonjol adalah rendahnya kualitas dan kuantitas pemanfaatan berbagai media elektronik. Padahal pada era globalisasi, media elektronik telah dan akan memainkan peranan yang sangat penting untuk menyampaikan aneka informasi dan mempengaruhi perubahan yang akan terjadi. Dalam konteks ini, kemampuan dan ketrampilan penggunaan media elektronik, utamanya media audio dan audio visual, serta kemampuan menejemen produksi siaran perlu ditangani oleh kompartemen khusus. Dari kompartemen ini peserta didik diharapkan akan meningkat kualitasnya dan terampil memanfaatkan berbagai media elektronika yang ada.

5. Media Tradisional (alat-alat music tradisonal)

Terdapat kecenderungan bahwa media komunikasi tradisional mulai ditinggalkan. Padahal kenyataannya di lapangan menunjukkan bahwa media tradisional, khususnya khotbah, pengajian dan kesenian masih cukup efektif untuk menyampaikan pesan-pesan dakwah. Oleh karenanya, kecakapan penggunaan media tradisional masih perlu ditangani oleh salah satu kompartemen di Laboratorium Dakwah.

\section{Media Cetak}

Untuk jangka waktu yang tidak terbatas, media cetak masih akan berpengaruh dalam penyebaran informasi kepada masyarakat dan pembentukan opini publik. Pada sisi yang lain, dakwah belum memanfaatkan secara maksimal media cetak tersebut. Oleh sebab itu, kemampuan tulis-menulis dan latihan-latihan jurnalistik pers merupakan kebutuhan mendesak untuk ditangani oleh kompartemen tersendiri dalam Laboratorium Dakwah.

7. Bimbingan dan Penyuluhan Agama (lab. Konseling).

Perkembangan masyarakat modern yang ditandai dengan kemajuan ilmu pengetahuan dan teknologi telah menawarkan berbagai kemajuan pada seluruh aspek kehidupan manusia. 
Namun demikian, tidak dapat dipungkiri bahwa kemajuan ilmu pengetahuan dan teknologi telah mengakibatkan berbagai problematika kejiwaan, baik pada level munculnya "mental disorder" maupun kehilangan orientasi diri dalam memanfaatkan lingkungan. Dalam suasana demikian, dakwah tidak dapat tinggal diam. Sebaliknya ia harus memasuki kawasan tersebut secara sistematis dan fungsional. Perintisan pusat "religious therapy" dan bimbingan agama secara umum merupakan alternatif yang harus diambil dan perlu ditangani oleh kompartemen khusus pula dalam Laboratorium Dakwah.

\section{SIMPULAN}

Fakultas Dakwah atau jurusan dakwah memiliki tugas dan tanggung jawab yang tidak mudah. Seiring dengan kemjuan ilmu pengetahuan dan teknologi juga menuntut peningkatan kualitas lulusan fakultas dakwah atau jurusan dakwah. Tuntutan ini memaksa fakultas dan jurusan dakwah untuk menyediakan fasilitas laboratorium dakwah yang memadai sebagai alat untuk mendongkrak kapasitas mahasiswa fakultas dakwah.

Seiring dengan itu pula maka pihak kementiran agama juga harus menyiapkan tenaga laboran untuk mengelolah laboratorium agar dapat berdayaguna dan berhasilguna. Hanya dengan hadirnya laboratorium dakwah dan laboran yang mumpuni akan memberikan dampak terhadap peningkatan kualitas lulusan fakultas atau jurusan dakwa. Dengan demikian kiprahnya akan terasa dan dibutuhkan oleh masyarakat.

\section{Endnote}

${ }^{1}$ Majid Tehranian, Global Communication and World Politics (London: Lynne Rienner Publisher Inc, 1999), h. 25.

${ }^{2}$ Ahmad Syafii Maarif, Membumikan Islam (Yogyakarta: Pustaka Pelajar, 1995), h. 101.

${ }^{3}$ Muhammad Tolhah Hasan, Prospek Islam dalam Menghadapi Tantangan Zaman (Jakarta: Lantabora Press, 2003), h. 13.

${ }^{4}$ Fathi Yakan, Problematika Dakwah dan Para Da'i (Solo: Intermedia, 2003), h. 232.

${ }^{5}$ Abdul Basit, Dakwah Wacana Kontemporer (Yogyakarta: STAIN Purwokerto Press dan Pustaka Pelajar, 2006), h. 61.

${ }^{6}$ A. Muis, Komunikasi Islam (Bandung: Remaja Rosdakarya, 2001), h. 159.

${ }^{7}$ Max Weber, The Protestant Ethic Spirit of Capitalism diterjemahkan oleh TW Utomo dan Yusup Priya Sudiarja dengan judul Etika Protestan dan Spirit Kapitalisme (Yogyakarta: Pustaka Pelajar, 2006), h. 29.

${ }^{8}$ Paul Daries, God and The New Physics (New York: Simon and Schester, 1983), h. 3 Lihat Sayid Mujtaba Musawi Lari, Ethics and Spritual Growth diterjemahkan oleh Muhammad Hasyim dengan judul Etika dan Pertumbuhan Spritual (Jakarta: Lentera, 2001), h. xv.

${ }^{9}$ Lihat Sayid Mujtaba Musawi Lari, Ethics and Spritual Growth diterjemahkan oleh Muhammad Hasyim dengan judul Etika dan Pertumbuhan Spritual (Jakarta: Lentera, 2001), h. xv. 


\footnotetext{
${ }^{10}$ Danah Zohar dan Ian Marshall, SQ: Memanfaatkan Kecerdasan Spiritual dalam Berpikir Integralistik dan Holistik untuk Memaknai Kehidupan, (Bandung: Mizan, 2001), h. 28.

${ }^{11}$ Max Weber, The Protestant Ethic Spirit of Capitalism diterjemahkan oleh TW Utomo dan Yusup Priya Sudiarja dengan judul Etika Protestan dan Spirit Kapitalisme (Yogyakarta: Pustaka Pelajar, 2006), h. 5758. 2003), h. xvi.

${ }^{12}$ St. Sularto, Niccolo Machiavelli Penguasa Arsitek Masyarakat (Jakarta: Penerbit Buku Kompas,

${ }^{13}$ Danah Zohar dan Ian Marshall, SQ: Memanfaatkan Kecerdasan... h. 27.

${ }^{14}$ Lihat Sayid Mujtaba Musawi Lari, Ethics and Spritual Growth diterjemahkan oleh Muhammad Hasyim dengan judul Etika dan Pertumbuhan Spritual (Jakarta: Lentera, 2001), h. 5.

${ }^{15}$ Danah Zohar dan Ian Marshall, SQ: Memanfaatkan Kecerdasan... h. 5.

${ }^{16}$ Lihat Tim Peneliti PSIK, Negara Kesejahteraan dan Globalisasi Pengembangan Kebijakan dan Perbandingan Pengalaman (Jakarta: Pusat Studi Islam dan Kenegaraan Universitas Paramadina, 2008), h. 272.

${ }^{17}$ Lihat M. Amin Rais, Moralitas Politik Muhammadiyah h. 25. 161.

${ }^{18}$ Zamakhsyari Dhofier, Dakwah Pembangunan (Yogyakarta: DPD Golkar DI Yogyakarta, 1992), h.

${ }^{19}$ Syamsul Munir Amin, Rekonstruksi Pemikiran Dakwah Islam (Jakarta: Amzah, 2008), h. 9-10.

${ }^{20}$ Nourouzzaman Shiddiqi, Dakwah dan Kaderisasi Pembangunan (Yogyakarta: DPD Golkar DI Yogyakarta, 1992), h. 179.

${ }^{21}$ Lihat M.Al Fandi, Optimalisasi Fungsi Laboratorium Dakwah Bagi Peningkatan Mutu Akademik Mahasiswa (Semarang: Fakultas Dakwah IAIN Semarang).

${ }^{22}$ Amrullah Ahmad, Makalah, Disajikan pada Workshop Laboratorium Dakwah pada Fakultas Dakwah IAIN Alauddin Makassar.
}

\section{DAFTAR PUSTAKA}

A. Muis, Komunikasi Islam (Bandung: Remaja Rosdakarya, 2001)

Abdul Basit, Dakwah Wacana Kontemporer (Yogyakarta: STAIN Purwokerto Press dan Pustaka Pelajar, 2006)

Ahmad Syafii Maarif, Membumikan Islam (Yogyakarta: Pustaka Pelajar, 1995)

Amrullah Ahmad, Makalah, Disajikan pada Workshop Laboratorium Dakwah pada Fakultas Dakwah IAIN Alauddin Makassar.

Danah Zohar dan Ian Marshall, SQ: Memanfaatkan Kecerdasan Spiritual dalam Berpikir Integralistik dan Holistik untuk Memaknai Kehidupan, (Bandung: Mizan, 2001)

Fathi Yakan, Problematika Dakwah dan Para Da’i (Solo: Intermedia, 2003)

M.Al Fandi, Optimalisasi Fungsi Laboratorium Dakwah Bagi Peningkatan Mutu Akademik Mahasiswa (Semarang: Fakultas Dakwah IAIN Semarang). 
Majid Tehranian, Global Communication and World Politics (London: Lynne Rienner Publisher Inc, 1999)

Max Weber, The Protestant Ethic Spirit of Capitalism diterjemahkan oleh TW Utomo dan Yusup Priya Sudiarja dengan judul Etika Protestan dan Spirit Kapitalisme (Yogyakarta: Pustaka Pelajar, 2006)

Max Weber, The Protestant Ethic Spirit of Capitalism diterjemahkan oleh TW Utomo dan Yusup Priya Sudiarja dengan judul Etika Protestan dan Spirit Kapitalisme (Yogyakarta: Pustaka Pelajar, 2006)

Muhammad Tolhah Hasan, Prospek Islam dalam Menghadapi Tantangan Zaman (Jakarta: Lantabora Press, 2003)

Nourouzzaman Shiddiqi, Dakwah dan Kaderisasi Pembangunan (Yogyakarta: DPD Golkar DI Yogyakarta, 1992)

Paul Daries, God and The New Physics (New York: Simon and Schester, 1983)

Sayid Mujtaba Musawi Lari, Ethics and Spritual Growth diterjemahkan oleh Muhammad Hasyim dengan judul Etika dan Pertumbuhan Spritual (Jakarta: Lentera, 2001)

St. Sularto, Niccolo Machiavelli Penguasa Arsitek Masyarakat (Jakarta: Penerbit Buku Kompas, 2003)

Syamsul Munir Amin, Rekonstruksi Pemikiran Dakwah Islam (Jakarta: Amzah, 2008)

Tim Peneliti PSIK, Negara Kesejahteraan dan Globalisasi Pengembangan Kebijakan dan Perbandingan Pengalaman (Jakarta: Pusat Studi Islam dan Kenegaraan Universitas Paramadina, 2008)

Zamakhsyari Dhofier, Dakwah Pembangunan (Yogyakarta: DPD Golkar DI Yogyakarta, 1992) 